\title{
ARABIC LITERATURE IN THE RISE OF ISLAMIC CIVILISATION AND THE PRESENT EDUCATIONAL SYSTEM
}

\author{
Suleiman Mohammed Hussein Boayo*
}

\begin{abstract}
Every given civilisation has foundations on which it rises. These foundations form the way of thinking for the people to whom that civilisation belongs, and define the scope within which they operate. The foundations differ from one civilisation to another; they may be a revelation, a divine or civil law, or customs and or norms that prevailed in a given society. Islamic civilisation sprung from the original Islamic sources, namely the Qur'an and the prophetic tradition. However, Arabic literature is seen as one of the additional foundations that have played a pivotal role in the rise of this civilisation, as well as in its development and flourishing. The purpose of this paper is to study critically some characteristic view-points of the relationship between Arabic literature and Islamic civilisation and to demonstrate the role Arabic language has played in the rise of this civilisation through its important periods. The outcome of this study will interpret Arabic literature as reflecting virtues and values, as revealing the ethos of different cultures of the Islamic civilisation, the processes of its rise and certain types of social facts. It will also illustrate the significance of teaching Arabic literature in the present day education, for it allows us to reach the heart of the Islamic civilisation through its literary, philosophical and political texts, along with its historical context.
\end{abstract}

Keywords: Arabic, literature, Education, Islam, Civilisation.

\section{Introduction: The Role of Arabic Literature in the Rise of Islamic Civilisation}

Our prophet (pbuh) had a clear vision, plans and programs on how to build a civilisation out of the religion of Islam that can face the challenges of the world right from the beginning of his mission as the messenger of God to mankind, to the moment of his departure from the world. Hence, when the Islamic civilisation is taken into account, one can argue that Islam in which this civilisation is rooted, arrived in this world to announce its existence through three interrelated circles, namely human, state and civilisation. It succeeded in building a good human being during the Meccan period, but it could not proceed to the second circle that was the establishment of a state. Obviously, without a state there will not be a civilisation. What blocked the way of Islam in achieving the other two goals in Mecca were political, social, religious and economic impediments. 
The migration of the prophet to Medina began when he realised that Mecca was not a proper place to build a state. There were many reasons for this, the most obvious ones were that the valleys of Mecca were surrounded by mountains, and the Ka'abah swarmed with idols. Therefore, it was impossible for a state to be established there, let alone a civilisation. Another reason was that, after a struggle that lasted for more than a decade, the prophet became certain that it was difficult for the idolatrous Meccan leaders to embrace the new religion. His migration to Medina was then justified by these tangible reasons.

Arabic language and literature were among the foundations that gradually helped to develop the Islamic Civilisation from the period of the prophet until the time of its decline. The holy Qur'an, in which this civilisation is rooted, was revealed in Arabic. The Prophet's mastery of this language contributed in designing the plans, building the institutions and fulfilling all the additional requirements for the new emerging civilisation. Besides this, Arabic literature preserved the Arabic language as the language of Islamic civilisation, and it played a significant role in its rise. For it made this civilisation to enjoy the beauty of its language through the sophisticated literary expression, the construction of correct and meaningful sentences, the articulation of the language according to the cultural, social, philosophical and political thinking of the Islamic civilisation. This was due to certain facts explored in Arabic literature through illustrating and parsing every single word and expression grammatically, morphologically, rhetorically and linguistically.

In this paper, I shall discuss briefly the role of Arabic literature and its components, namely prose, oration and proverbs in the rise of the Islamic civilisation. These elements will be covered under the section of pre-Islamic, early Islamic, Umayyad and Abbasid periods. The role of grammar in the Arabic language and its literature cannot be neglected because it has equal importance as the other components, which will also be discussed.

\section{Status of Arabic Literature in the Pre-Islamic Period ('Asr al-Jāhilī)}

It is necessary to explain the term jähiliyyah in this context, because there is a general misconception that it means sheer ignorance, simply because it is an antonym of knowledge. The meaning of the term jähiliyyah is not derived from al-jahl (ignorance), which is the opposite of knowledge. In this context, it is from Jahl, which means foolishness or silliness in behavior or in conduct, being ill-tempered or quickly becoming angry and disdainful, as well as acting in an uncivilised manner. What justifies this meaning is the statement of the Qur'an:

And the servants of (God) Most Gracious and those who walk on the earth in humility, and when the ignorant address them, they say peace. ${ }^{1}$ 
The ignorant in this verse refers to foolish or silly people who behave in an uncivilised way. This is brought into account to clarify this misconception, so that it will not amount to a belief that the Arabs of the pre-Islamic period were ignorant, uneducated and had no share of knowledge. As a result they were in complete isolation from other educated and civilised people. ${ }^{2}$ They were against life in towns, because they were proud of their own way of life and activities as bedouins. One of their poets Al-Qattāmi states:

He who has been attracted by the sedentary life,

Then what kind of rural men does he see us to be.

We attack neighbors wherever they are,

When we are destitute for robbery.

We attack whoever the time has come for,

In the cold morning at dawn.

Sometimes it is ... our own brother,

If we could not find anybody except him. ${ }^{3}$

In these poems al-Qattami boasts of the Bedouin way of life of his tribesmen over that of the town dwellers, and the attacks on people even on their relatives when there is a need for that. It was this type of life the Qur' an has called jāhiliyyah and states: "Do they then seek after a judgment of the days of ignorance? But who, for a people whose faith is assured, can give better judgment than God."

Regarding their activities and the economic life, there were contacts between them and other nations. They had two commercial trips, one to Al-Sham where Rome was situated during the summer, and the others to Yemen, Ethiopia and Persia in winter. "Their covenants covering journeys by winter and summer." Based on this explanation, it is unfair to think that the term jähiliyyah or hayat jāhiliyyah refers to sheer ignorance.

Shi ir or poetry will take a lion's share of our discussion because of its importance in Arabic literature. Even literary critics who dealt with the subject of the classification of poets and their poetry, when they refer to adab (literature) they mean shi ir (poetry) only, ${ }^{6}$ but there are other parts of the literature such as nasthr prose, khitābah oration, amthāl proverbs and hikam wisdom sayings.

The word adab, which is known in Arabic language as literature, has another meaning, which is good behavior, respect and politeness in dealing with other people. It can be defined as an ethical quality of the soul, good upbringing, urbanity and courtesy. ${ }^{7}$ In the Middle Ages it referred to a banquet or special invitation. It was implied to mean the etiquette in eating, drinking and clothing, the etiquette of the boon companion, the etiquette of disputation and the etiquette of study and teaching. Starting from the first century of the Hijrah, it was employed to refer to the intellectual sciences as distinct from religious knowledge. In the third to ninth 
century, Jāhiz emerged as a prominent $a d \bar{i} b$ poet of Arabic poetry (shi'ir), prose (nathr), and ethics (akhlaq). ${ }^{8}$ The main elements of adab are moral and social upbringing, intellectual education and entertainment. ${ }^{9}$

The word shi 'ir is derived from sha 'ara; for example, sha 'ara fülan shi 'iran, "he says poetry." Sha 'ara bihī shu 'üran means, "to sense it and to know it." And sha 'ura fulān shi iran: means "to possess a skill in poetry and to master it." 10 For example, yā layta shi 'irī means "I wish I knew." 11 According to Al-Jurjani, al-shi' ir (poetry) literally means knowledge; technically, it is a rhymed statement with meters composed with intention, and because of this last condition we can exclude, for example, the Qur'anic verse: Allazī anqada zahrak, wa rafa 'anā laka zikraka. This verse is a rhymed statement, yet it is not poetry, though it is composed with meters and rhymes, but it is not intended to be poetry. ${ }^{12} \mathrm{He}$ further states that in the terminology of logicians, shi 'ir is "an analogy which consists of mukhayyalät (imaginations), and its intention is reaction of the soul to the desired and undesired things, (al-targì wal al-tanfir), for example, the poets in their poetry do call alcohol yāqūt sayyāh (liquid ruby), and honey murrah muhwi'at (vomiting bitter). ${ }^{13}$

In the Qur'an the words shi 'ir (poetry) and sha 'ir, (a poet), the plural of which is shu 'arā, are mentioned. In surah al-shu 'arā the famous verse:

And the poets, it is those straying in evil, who follow them, seest thou not that they wander distracted in every valley? And that they say what they practice not? Except those who believe, work righteousness, engage much in the remembrance of God, and defend themselves only after they are unjustly attacked. And soon will the unjust assailants know what vicissitudes their affairs will take. ${ }^{14}$

The surah from which this verse is quoted chronologically belongs to the middle Meccan period, during the encounter of the prophet with the pagans of Mecca. The prophet's message was resisted by the votaries of evil, but the truth is not like vain poetry, and ought to triumph at last. The lesson learnt is this surah is that the Qur'an is pure truth unlike poetry of vain poets, and that the prophet, according to the Qur'an: "He does not speak (yantiqu) of his wish, it is but what has been revealed unto him."15

For this reason, we see that other verses in the Qur'an repeatedly stress the difference between the purity and authenticity of the truthfulness of the message that the Qur'an reveals to the prophet and the poetry of vain poets, which does not bear any truth. We can deduce this understanding from the following Qur'anic verses: "We have not instructed the prophet in poetry nor is it meet for him; this is no less than a message and a Qur'an making things clear." "Nay they say these are medleys of dream! Nay he forged it! Nay 
he is but a poet! Let him then bring us a sign like the ones that were sent to prophets of old." 17 "And say: what! Shall we give up our gods for the sake of a poet possessed?" 18 Or do they say: a poet! We await for him some calamity hatched by time. ${ }^{19}$ It is not the word of a poet, little it is ye believe! ${ }^{20}$ We do understand from these verses that the Qur'an does not refer to the language of poetry or to the beautiful composition of its phrases, but to the truthfulness of the substance in it. Besides, it is not the entire shi 'ir poetry that was evil. This can be justified by the hadith of the prophet: "Surely there is wisdom in some poetry, if something becomes obscure or ambiguous before you in the Qur'an (in terms of the language) you should search for it in the poetry, verily it is a classical Arabic language." 21

Arabs were known for their poetry, it was popular and it spread widely, for it was a record of their pride, dignity as well as news of their tribes and relatives. Jāhiz says: "Every mankind or nation depends on the continuation of their heritage and the protection of their virtues. Therefore, the Arabs in their jăhiliyyah times strived to preserve that by depending on the poetry which was put in meters and the rhythmic speech and that was their book of the treasury." ${ }^{22}$ Ibn Qutaybah made a similar remark: "Indeed God made poetry as a treasure for the sciences of the Arabs, as a protection for their literature, as a book of record for their linage and news; it does not become ragged or damaged across the time. ${ }^{23}$

It is worth mentioning that during this period, every tribe had a poet, and the role of the poet was to defend kinship and the dignity of the tribe he belonged to. Poetry was considered as an important means of communication. It was known that every tribe burst into celebration in the event that a poet sprung from it.

There were many good ideas and elements in pre-Islamic poetry, such as encouragement of seeking knowledge, politics, justice, freedom, advice and ethics. Tarafah bin al-Abdah's poetry was famous for ethical ideas, Hārith bin Hillizah for knowledge and Zuhair bin Abī Sulmah for wisdom (al-hikmah) amounting to philosophical theories. ${ }^{24}$

Prose was another important component of Arabic literature in pre-Islamic times. It included advice which sprung from their experience of life. A prominent figure in this field was Ibn al-Hārith bin Muhrith bin al-Zarb, known for orations; Qass bin Sā'adah al-Iyādī was one the popular orators. Other types of literature included proverbs, oracular sayings, and stories of love, adventure and entertainment. There were other poets whose ideas were right and good for human civilisation, but these did not emerge until the arrival of Islam. 


\section{Poetry (Shi'ir) in Early Islam}

The civilisational ideas and elements in the poetry and prose of the pre-Islamic era were brought to early Islamic period. However, to discuss the role they played in this early period of Islam, it is noteworthy to make it clear that when Islam came, it rejected unethical poetry of the pre-Islamic period on account of various ideas that were perceived as being against Islamic principles, such as poetry describing women features, igniting flames of wars between the tribes, and inciting oppression of the weak by the strong.

Hence, during the early period of Islam, poetry was purged of these kinds of negative elements. Some veteran poets, such as Hassān bin Thābit, Abdullah bin Rawwāh and others, were even classified as Islamic poets.

The influence of Islam on the poets and their poetry was very obvious. 'Umar bin Khattāb once sent for Lubaid bin Rabia'at al-'Amirī, who was among the poet-writers, and asked him to write poems on Islam. Lubaid went to his house and wrote surah al-Baqarah on paper, brought it to "Umar, and said to him: "This is what Allah has substituted for me in Islam in the place of poems." ${ }^{25}$

Hassān bin Thābit's poems uplifted the morals of the prophet's civilising mission. He composed poems to silence the non-believers among the Quraish people, and to halt them from hindering the prophet in continuing his mission toward laying the foundations of the Islamic civilisation.

According to some sources, poetry (shi ir) was recorded during the time of jāhiliyyah by virtue of the fact that writing was already known at that time. And when the Qur' an was revealed, it called on the Arabs to employ writing in some of their business transactions to secure their rights. ${ }^{26}$

There is a difference of opinion among scholars on the issue of books. ${ }^{27}$ However, there were indications that some recording of literature already took place during the early period of Islam. One of these was the use of special terms used in the process of recording, such as al-daftar, al-karrāsah, al-kitāb and almushaf. These terms were classical Arabic terms. They were used in both preIslamic and early Islamic poetry. ${ }^{28}$

Books of military campaigns and the biographies of the prophet, al-maga $\bar{a} \bar{\imath}$ wa al-siyar, were also recorded alongside hadith and tafsir , and contained lots of poetry composed by pre-Islamic poets and veterans. They were the materials that many commentators of the Qur'an resorted to in order to identify the causes of revelations, ascertain citations and for the purpose of understanding the meaning of the unusual terms. ${ }^{29}$

Some of the companions of the prophet were eager to record poetry. Therefore, the permission given by Umar bin Khattāb for pre-Islamic poetry to be written down was not an innovation. Umar bin Khattāb, while on the podium giving 
sermon one day, asked: "What are you saying in it?" He was referring to the Qur'anic verse: "Au ya'akhuzuhum 'alā takhawwufin 'Or that He may not call them to account by a process of slow wastage, for thy Lord is indeed full of kindness and mercy." Everybody was mute; an old man from Huzail tribe stood up and said: "This is our language, our dialect. Takhawwuf means attanaqus." "Umar then asked, "Do the Arabs know that in their poetry?" He said, "Yes, our poet Abu Kabīr described his she-camel," and he recited the poem. Umar said: "You must hold on to your book of the treasure, you would not go astray." The companions said: "What book do you mean?" He said: "Shi 'ir jāhiliyyah, surely there is in the commentary of your book the meaning of your speech." ${ }^{30} \mathrm{Ibn}$ Abass was also aspired by pre-Islamic poetry. It is narrated that an Arab bedouin came to him and said: "Takhawwafan̄ mālì akhun lì zuāalimun, falā takhzuln̄̄ al-yauma yā khaira man baqiya." Then Ibn Abbas said: "Takhawwafaka means tanaqasska," and the bedouin said "Yes," and then he said: "God is great!" And he recited the same Qur'anic verse mentioned earlier. He was an avid admirer of pre-Islamic poetry and urged people to learn it, and to employ it in commenting on the Qur'an. On that occasion he stated: "If you are asked about something concerning strange words in the Qur'an, you should search for it in the poetry; surely it is the book of treasure of the Arabs." ${ }^{31}$ In a nutshell, the existence of poetry in this period was obvious. Tāhā Hussein declared that when we look at the Islamic countries during this period of Islam, we find that poetry existed and flourished in some of the regions, but it barely existed in others. It existed and flourished in al-Hijaz and Iraq and in its urban and rural areas. In Al-Sham, there was little poetry as one could hardly find a poet except for one or two. The poetry that we find in al-Sham during the Umayyad period was brought there from other regions. ${ }^{32}$

\section{Poetry (Shi'ir) in the Umayyad Period}

Poetry improved in this period, in terms of its linguistic diversity, rhetorical expression and other artistic merits, to the extent that they were far superior to those of pre-Islamic poetry, and "the reason for it [is] that those who lived under Islam benefited from the model of high-class speech provided by the Qur'an and Hadith." ${ }^{33}$

In this period, Al-Walīd bin Yazīd collected a lot of poetry written by Arabs and recorded it, but he was not the first to do so. Those who preceded him among the caliphs of the Umayyads did the same. Walid bin Abdul Malik for example had a special writer whom he charged with collecting and recording poetry as well as news about Arabs. Abdul Malik bin Marwan requested his writers to write down the commentary of the Qur'an for him, and when they finished, he kept it 
in the diswan. He treated poetry the same way he treated the commentary of the Qur'an. He had even gone beyond this and authorised his writers to collect al$m u$ 'allaqāt for him..$^{34}$ There was a humanistic kind of literature (adab) that taught politeness and imparted culture, which took on a nationalistic character during the time of the Umayyad régime, and that was when the poet become an expert in the knowledge of the ancient Arab poets.

\section{Shi'ir in the Abbasid Period}

When the Arabs conquered Iraq, Iran, Sham and Egypt, they started to absorb various elements of other civilisations into their own. The caliphs, ministers, mayors and leaders in this period were extremely generous to scholars and poets. Amin exaggerated his generosity, when he approved a daily payment of hundred thousand of dirhams to a poet called Abdullah bin Ayub al-Taymi. These floods of gifts to scholars, physicians and poets had a huge impact on the renaissance in the sciences, literature and the arts. ${ }^{35}$

Poetry improved greatly during this period. The main reason for this was the development of the social life within the Islamic civilisation, and the interaction between the Arabs with other nations, namely Persians, Byzantines and Egyptians. They benefited from their thoughts, ideas, and experiences. Also, great importance was attached to poetry by the rulers. They showered the poets with precious gifts. This led to a rapid renaissance of new ideas. Many literary and scientific works were translated into Arabic from other languages. The poets of this period followed in the steps of their predecessors in composing poems. They developed the old objectives of poetry as well as identified new ones. The new objectives included admonition and asceticism. A prominent figure in this field was Abu al-'Itāhia. Another novelty was educational and character-building poetry. A well-known figure in this area was Aban, who composed poems about the rules of fasting and alms giving. Other well-known poets at this period included Bashār bin Burd, Abū Nawwās, Abū Tammām, Ibn Rūmī, Al-Buhtury, Abū Tayyib al-Mutanabbī and others. Popular topics in Arabic poetry included al-rathā (elegiac poetry), al-madīh (eulogy), al-hijā (defamatory poetry), al-wasf (description), al-nasīb (amatory) and al-mujūn (impudence).

The prose in this period reached its zenith of beauty. The art of writing developed tremendously. Many new elements were added to it, which were not known even during pre-Islamic times. It is important to mention the influence of the holy Qur'an and the hadith in the prose of this time. The most important contribution of the Qur'an and the hadith was the recognition of the need to state clearly the purpose of speech, to choose the right words, and make the content conform to the aim of speech. 
The political and social conditions of the period motivated people to learn. Among the well-known figures in this domain was "Al-Jahiz (d.255/868-69). His "Book of Animals" is a fine specimen of an amalgamation of art and science. Ibn al-Muqafa's social prose was also well known. He was Persian and represented this trend in Arabic literary prose. Kalīlah wa Dimnah, his most popular work in Arabic literature, is a translation of the Pahlavi version of An Indian Marrow of Princes, a work which centers on moral improvement and intellectual refinement. ${ }^{36}$ His other work, which serves the same purpose, is al-Adab al-Sagitr; the first part of the book treats rulers and the second, friends. One observes that the intermingling of different cultures and norms widened the domain of adab to include Arabic poetry and prose, Persian literature of the epic, gnomic and narrative tradition, the Indian world with its fables, and the Greek world with its practical philosophy, especially in ethics and politics. ${ }^{37}$ Story cycles, high-class fiction, literacy epistles (risāil) and rhetorical works (maqāmāt) all contributed to the flourishing of prose in this period..$^{38}$

The proverbs (al-amthāl) as essential components of Arabic literature and their role in the rise of the Islamic civilisation, cannot be overstated. Pre-Islamic Arabs were scrupulous in writing down proverbs and preserving them. Evidence of this can be found in the fact that among the first works recorded by the Arabs during early Islam was the 'Books of Proverbs.' Other books of proverbs, such as that of Sahara bin 'Ayyāsh al-Abdi, were written since the reign of Mu'āwiyah.

Concerning the khitābah (oration), "It is an art of the public speech for the purpose of convincing and winning the hearts of people." ${ }^{39}$ Arabs knew it as they knew poetry. The word is mentioned in the Qur'an in the aforementioned verse: "And the servants of (God) Most Gracious and those who walk on the earth in humility, and when the ignorant address them, they say peace." ${ }^{\prime 4}$ Every tribe possessed an orator as they did in the case of poetry. The orator was the official spokesman of his tribe in wars, hopes, ambitions, happiness and sadness. The oration had huge impact on pre-Islamic tribes, in terms of their unity, power, prestige and respect from the other tribes. They employed their orations in the services of the tribe as well as individuals, and for establishing good relations with other tribes. The oration from the beginning was considered as a weapon in peace, in war and in striving to realise tribal aspirations. Therefore, it was not unusual for the oration to be considered as a communiqué to guide people, to call them to the worship of Allah, and to abandon associating Him with other beings. The oration had tribal, political, religious and social objectives. These were periodically discussed on communal occasions. The oration was intended to strengthen the determination of the members of the tribe and to inspire them with high ambitions. As for religious objectives, the holy Qur'an had a great influence on them, because even before Islam, the aims of the orators included 
participating in religious rituals and customs that were practiced before Islam. But when the holy Qur'an came with Islam, the orators started to mimic its ways of expressions, adapting, quoting and citing them. ${ }^{41}$

Al-khitābh consisted of various types, namely al-hamāsiyyah, (enthusiastic) al-wa'aziyyah, (admonition) al-mausimiyyah, festival al-rasmiyyah (ceremonial) and al-amlāk (possession). The content of khitābah was typically composed of three parts, namely al-muqaddimah (introduction) al- 'ard (body of presentation) and al-khätimah (conclusion). The characteristics of al-khatīb (orator) were also of utmost importance. ${ }^{42}$

It is worth mentioning that al-khitäbah played an important role in the rise of the Islamic civilisation. The aims it fostered included freedom, the ambition of the ummah to a better life, the eradication of illiteracy, bringing wars and revolutions to an end, and an ability to accommodate a multiplicity of political parties.

\section{Role of Grammar and Grammarian}

At the end of the Umayyad period a large group of scholars in Basrah and Kufah developed an interest in collecting the expressions within the Arabic language and preserving the poetry of the Arabs, from both pre-Islamic and Islamic periods. One of the most important reasons behind this campaign was the dire need of foreigners who converted to Islam to learn the language of the holy Qur'an. Another reason was the spread of errors in the use of Arabic among both the Arabists and the Arabs themselves.

Three consecutive generations of Basran and Kufan scholars were active in the collection and systematisation of the Arabic terms and Arabic poetry. The leader of the first generation in this important project in Basrah was Abu 'Amru bin 'Alā $(\mathrm{d} .154 \mathrm{H})$. He was a recognised authority in his field. Jahiz states: "He was the most knowledgeable of the people in rare words, the Arabic language, the Qur'an, the poetry and the history of Arabs and of other people." ${ }^{43}$ The grammarians would seldom come across good poetry from the pre-Islamic or Islamic period without making sure that they recorded, illustrated and explained it. These efforts made it easier for the contemporary poets as well as for other people to learn good Arabic and to use it well.

According to Shawqī Daif, the main reasons that induced the grammarian of this period to undertake this painstaking work were the Qur'an and the prophetic traditions. They did not want the meaning of these two main sources of the Islamic civilisation to become ambiguous in the understanding of people and the scholars themselves. He quoted Jāhiz as stating:

Arabs do possess proverbs, etymology of words, morphological structures and the coinage of speech, which signify what they mean 
and intend to say. He, who does not know them, becomes ignorant in interpreting the Qur'an and the prophetic tradition. And he who studies these speeches and these kinds of sciences and he is not from this field of specialisation, ruins himself and ruins other people. ${ }^{44}$

In addition to this, since the Qur'an and the hadith are the two main sources of the Islamic civilisation, the caliphs of Abbasid era made a determined effort to protect the language of the Qur'an and hadith. They sent scholars to various places to study Arabic, and to gather the knowledge of all that is related to it, including genealogy, history and poetry.

The intellectual life of this period flourished, because of lots of books were translated into Arabic from Hindi, Persian and Greek. As we have mentioned earlier, Kalīlah wa Dimnah, whose Persian translation from Hindi was rendered into Arabic by Ibn Muqaff"a, significantly impacted the wise sayings and proverbs during the Abbasid era. ${ }^{45}$

When Islam came, Arabic was rich in various forms of expression. It also had a literary heritage for expressing different types of heartfelt and social sentiments; the language was wonderful since the pre-Islamic period.

The Arabs were eloquent people, the ' $u k \bar{a} z$ market was the place where poets and men of letters and rhetoric assembled to compete with one another in their poetry. For this reason, Arabic was purified from various errors. Consequently, classical Arabic became the official language of every tribe. But when the Arabs began to interact with foreigners after the expansion of Islam into neighbouring lands, people began to commit errors in the language. So the need for grammar to salvage the language became evident.

Many sources agreed that the study of Arabic grammar started in al-Basrah, where it was nurtured and developed. The scholar who initiated the study of Arabic grammar was Abu al-Aswad al-Duali $(\mathrm{d} .67 \mathrm{H})$. There were two schools of thought on Arabic grammar, the Basran and the Kufan Schools. The tribal tension between the people of these two famous towns in Iraq was always conspicuous. The conflicts between them, however, turned into political and intellectual discourse. As a result, many discussions, disputes and debates occurred between them. One such debate for example, was the famous debate between Sībawaihī and al Kisā'̀̄.

In other debates the relative importance of grammar and logic was discussed. The debate between Abū Bishr Matta Ibn Yūnus, and the grammarian, Abū Sa '̄id al-Sīräfĩ was one example. The main reason for this debate was provided by Abu Bishr declaration: "The logician has no need for grammar, whereas the grammarian does need logic; since logic enquires into the sense, whereas grammar enquires into the sound." ${ }^{46}$ Al-Sīrāfì as the grammarian rose to the 
occasion and debated Abū Bishr vehemently in favor of grammar. Scholars, such as Muhsin Mahdi believed that the debate was considered in the literary and academic milieu of Baghdad a victory of grammar over logic, as well as a victory of the grammarians and theologians over logicians and philosophers. ${ }^{47}$

According to early sources, Abu al-Aswad al-Duali was the leading scholar in al-Basrah, where his students taught Arabic grammar. He invented the vocalisational signs of al-raf'a, al-nasb, al-jarr, and al-tanwin. These were known as "Dots of Abu al-Aswad al-Dualī." This could well have been the most important service he contributed to the development of Arabic grammar, as this was one of the first steps in this direction. Also, his students Nasr bin 'Asim and Yahya bin Ya'mar introduced the use of the single and double dots that are used with Arabic letters to distinguish them better from each other, such as $a l-b \bar{a} ' a$, $a l-y \bar{a} ' a$ and $a l-n \bar{u} n .^{48}$

One will not be able to enumerate all the scholars of this school and their contributions to Arabic language and literature. But one could mention al-Khalīl Ahmad al-Farāhīdī. He became known for his identification and clarification of a number of obscure terms in Arabic. He was the first to discover the science of metrics or prosody (' $\mathrm{ilm}$ al- 'arüd) and to apply it in the study of poetry. He was also the author of a book, the first of its kind in this area, that explored the accuracy of language, kitāb al-'ain. Sībawaihi and his book al-kitāb are considered to be the zenith of Basran grammar school of thought.

Abu Ja'afar al-Ruwasi was a prominent figure within the Kufan school of thought, the rival of the Basran school. However, he also sought knowledge in al-Basrah. He schooled first under Abu 'Amru bin al-'Alā, and later under Issah bin 'Umar al-Thaqafĩ. He was the first Kufan to write a book on Arabic grammar entitled, al-Faisal. Al-Kisāī and al-Farrā also became very famous within the school; both were students of Abū Ja'afar.

The differences of opinion and robust debates about grammar between these two schools were initially due to the personal proclivities and political tendencies of the participants. These later turned into intellectual narrow-mindedness between the two schools. Yet, the results brought tremendous benefits to the development of the Arabic language and literature, which greatly contributed to Islamic scholarship and the rise of the Islamic civilisation.

The most popular works in the field of the Arabic grammar are al-Kitāb of Seebawaihi, al-Tasrīf and al-Munasaf of Ibn Jinnī, al-Muffasal of alZamakhsharī, Lam'al-Addilah of Ibn al-Anbār, al-Al-fiyyah of Ibn Mālik and Mugni al-Labeed and Shuzūr al-Zahab of Ibn Hishām. These works represent different commentaries by different scholars. It is worth mentioning that Arabic grammar subsumes other subjects relevant to it, namely lexicography, rhetoric, morphology and linguistics. 


\section{Mother Sources of Arabic Literature Al-Masādir Al-Adab Al-'Arabī}

In addition to books on Arabic literature based on a broad meaning of literature, there are other books, with distinctive characters and methods with specific objectives, such as the books of the classification of poets, in which the poets were classified since the pre-Islamic period. 1-Al-Bayan wa al-Tabyin of Abu Osman Amru bin Bahr al-Jahiz. 2-Al-Kamil of Muhammad bin Yazid al-Mabrad. 3- 'Uyun al-Akhbar of Abdullah bin Muslim bin Qutaibah. 4-Al-Iqd al-Farid of Ibn 'Abd Rabuh al-Andalusi 5-Kitab al-Agani of Abu al-Faraj al-Asfahani. 6Nihayat al-Arab fi funun al-Adab of shihab al-Din al-Nuwairi.

The different categories of the sources of Arabic literature are: 1-Kitab al-Amali of Abu 'Ali al-Qali, 2-Tabaqat al-Shuara of Ibn Sullam al-Jumahi. 3-Mu'ajam al-Shu 'ara of al-Marzabani. 4-Mu 'ajam al-Udaba of Yaqut al-Hamawi. 5-Nafh al-Tiyyib min Gusn al-Andaws al-Ratib of Ahamad bin Muhammad popularly known as al-Maqqari. ${ }^{49}$ One should not forget linguistic and lexicographic sources.

\section{Conclusion and Recommendations}

Important issues arising from the discussion above with regard to the status of the Arabic literature and its components, namely poetry, prose, oration and proverbs in the pre-Islamic period, during early Islam, and throughout the Umayyad and the Abbasid periods include: (1) the Arabic literature contained distinctive civilisational features, (2) Arabic literature played an important role in the rise of the Islamic civilisation, and (3) while Arabic poetry cannot be called a philosophical work, it is of great value in so far as it provides valuable insights into the various stages of the Arab and non-Arab way of life. Similarly, the educational influence of Arabic poetry on Muslims and non-Muslims cannot be under estimated.

Arabic literature and its components should be taught through translation. The recommended method is to keep close to the Arabic, while allowing the English idiom to develop its natural strength, and making adjustments as required by the sophistication of the originals.

- Literature plays an important role in civilising a given society.

- Literature can play a significant role in helping to achieve civilisational renewal.

- Prizes and funding should be made available to aspiring young writers.

- Literature has an important ethical role to play in education.

- Literature should be guided by the knowledge of the Qur'anic revelation and the example of the prophet as contained in the collected works on the prophetic traditions. 


\section{Notes}

* Suleiman Mohammed Hussein Boayo is a senior lecturer at at the Center for Advanced Studies on Islam, Science and Civilisation (CASIS), Universiti Teknologi Malaysia. Prior to his appointment at CASIS, he served as an Academic Fellow at International Institute of Islamic Thought and Civilization (ISTAC), from 2007 to 2009, and as an Assistant Professor at the Department of General Studies, International Islamic University Malaysia, from 2009 to 2012. $\mathrm{He}$ obtained his Ph.D. in Islamic Civilizations, from International Institute of Islamic Thought and Civilization (ISTAC), Kuala Lumpur in 2006.

1. Al-Furqān, 25:63. Translations of all Qur'anic verses in this paper are based on Abdullah Yusuf Ali, The Holy Quran: Original Arabic Text, with English Translation \& Selected Commentaries (Kuala Lumpur: Saba Islamic Media Sdn. Bhd., 1998).

2. For more information on the contact of Arabs to other past civilisations see, AlAsad, Nasir Al-ddin, Masādir al-Shi 'ir al-Jāhilī wa Qīmatuhā al-Tārīkhiyyah, $7^{\text {th }}$ ed. (Beirut: Dar al-Jîl, 1988), pp. 18-19.

3. Saba, Tawfiq Mohammad, Qiyam Hadāriyyah fi al-Quran al-Karim (Cairo: Dar al-Manār, 1984), p. 21, Al-Qattami is 'Umair bin Shuyyim al-Nasrānī al-Taglabī, he was contemporary of Al-Akhtal who is also Amawi. The translation of these poems is mine.

4. Al-Mā'idah, 5:50.

5. Quraysh, 106:2.

6. Al-Majālī̄, Jihād, Tabaqāt al-Shu'arā fì al-Naqdi al- 'Adabī 'inda al-'Arab. $1^{\text {st }}$ ed. (Beirut: Dar al-Jīl, 1992), p. 59.

7. H. Kilpatrick, 'Adab', Encyclopaedia of Arabic Literature, (London, 1998), p.56, see chapter 10.

8. F. Gabrieli, 'Adab', Encyclopaedia of Islam, new ed. vol. 1, p. 175.

9. H. Kilpatrick 'Adab', Encyclopaedia of Arabic Literature, pp. 56-7.

10. Al-Muajam al-Wajiz, Majma'a al-Lugat al-Arabia (Cairo: Dar al Tahrir liltabi wa- al-Nashr, 1973) p. 344.

11. Ibn Manzūr, Lisān al-'Arab, vol. 4, (Beirut: Dār al-Ma'ārif, undated), pp. 2273-4.

12. Al-Jurjānī, Ali bin Muhammad, Al-Ta 'arīfāt, $1^{\text {st }}$ ed. (Cairo: Dār al-Kitāb alMasry), p. 140.

13. Ibid, p. 140.

14. Al-Shu'arā, 26:224-227.

15. Al-Najm, 53:3-4

16. Yasin, $36: 69$

17. Al-Anbiya, 21:5

18. Al-Naml, 27:36

19. Al-Tur, $52: 30$

20. Al-Haqqah, 69:41

21. This hadith is quoted from Ibn Manzūr, Lisān al- 'Arab, vol. 4, (Beirut: Dār alMa'ārif, undated), pp. 2273-4.

22. Al-Asad Nasir al-addin, Masādir al-Shi 'ir al-Jāhilī wa Qīmatuhāal-Tārīkhiyyah, $7^{\text {th }}$ ed. (Beirut: Dar al- Jīl, 1988), p. 109.

23. Ibid, p. 109. 
24. Farrukh,'Umar, Al-Fikr Al- 'Arabī. (Beirut: Dar 'ilm Lilmalāyīn, 1996), p. 170.

25. Al-Asad Nasir al-addin, Mașādir al-Shi ‘ir al-Jāhilī wa Quiyamuhā alTārikhiyyah, p. 115.

26. Ismail, 'Izzudin, Al-Masadir al-Adabiyyah wa al-Lugawiyyah fì al-Turāth al'Arabi, (Beirut: Dar al-Nahdah al-Arabiyyah.1975), p. 14.

27. It is known that the recording of the linguistic, poetry and general Arabic literature did not take place except at the end of the second century and the beginning of the third century of hijrah; however, some scholars deny this late date. The available recordings, which were ascribed to the men of letters of the end of the second century, were only verbal lessons, they did not write them down; rather it was written down by their students or by the students of their students and then ascribed by them to their teachers. See, in the footnotes in Al-Asad Nasir aladdin, Mașādir al-Shi ìr al-Jāhilī wa Quiyamuhā al-Tārikhiyyah, p. 134.

28. Ibid, p. 138.

29. Al-Asad Nasir al-Addin, Mașādir al-Shi'ir al- Jāhilī wa Qìmatuhā alTārīkhiyyah, p. 151-2.

30. Ibid, p. 152.

31. Ibid, p. 152.

32. Tāhā Hussein, Min Tārīkh al-Adabi al-'Arabī (Beirūt: Dar 'Ilm Lilmalāyīn, 1970), pp. 69-70.

33. M.M. Sharif, A History of Muslim Philosophy Vol. 2 (Wiesbaden, 1968) p. 996.

34. Al-Asad Nasir al-Addin, Mașādir al-Shi 'ir al-Jāhilī wa Quiyamuhā alTärikhiyyah, p. 158. Mu'alaqät consisted of ten or seven poems chosen by the Arabs from old poetry, which was written with golden ink and hanged on the curtains of the Ka'abah. This practice was due to the attachment of Arabs to the poetry.

35. Daif, Shawqi, Tārīkh al-Adab al-'Arabī, Al-'Asr al-'Abbasī al-Awwal, $6^{\text {th }}$ ed. (Cairo: Dar al- Ma'ārif: 1966), p. 48.

36. This work was first published by Matba'at Karam in Damacus Syria in 1957.

37. Gabrielli, 'Adab', Encyclopaedia of Islam, p. 175. On Ibn Muqafa'a and his contribution to adab, see, Moralia: Les Notions morales dans la Literature Persane du 3e/9e au 7e/13e siècle, Moralia: The moral notions in Persian literature form the $3^{\text {rd }} / 9^{\text {th }}$ to the $7^{\text {th }} / 13^{\text {th }}$ century, by Charles-Henri de Fouchecuor, Institut Français de Recherché en Iran, Paris, 1986, pp. 414-20.

38. M.M. Sharif, A History of Muslim Philosophy Vol. 2 (Wiesbaden, 1968), p. 107.

39. Al-Janābī, Abdul Karim Ibrahim, Tārikh al-Khitābah al-'Arabiyyah. (Cairo: Maktabat al-Thaqāfiyyah al-Dīniyyah, 2005), p. 20.

40. Sūrah Al- Furqān: 63.

41. Al-Janābī, Abdulkarim Ibrahim, Tārikh al-Khitābah al-'Arabiyyah, p. 23.

42. Ibid, pp. 24-34.

43. Daif, Shawqī, Tarikh al- Adab al- 'Arabī, $6^{\text {th }}$ ed. (Cairo: Dar al- Maarif, undated), p. 119. See also, Al-Jāhiz, Abu 'Usman 'Amru bin Bahr, Al-Bayān wa al-Tabyīn, edited by Abdu al-Salam Harun, $2^{\text {nd }}$ ed. (Cairo: Maktatabat al-khanji in Egypt and Al-Muthana in Baghdad, 1960).

44. Ibid, p. 139. See also, Al-Jāhiz, Al-Hayawān, edited by Abdu al-Salam Harun, $3^{\text {rd }}$ ed. (Beirut: Dar al-Kitab, 1969). 
45. Ibid, p. 149.

46. The Discussion between Abū Bishr Matta and Abū Sa'īd al-Sīrāfì on the Merits of Logic and Grammar. The Journal of the Royal Asiatic Society, 1905, p.116.

47. Al-Fārābī, Kitāb Al-khurūf, (Book of Letters), edited by Muhsin Mahdi, $2^{\text {nd }}$ ed. (Beirut: Dar El-Mashreq publishers, 1990), p. 47.

48. Al-Afghān̄̄, Saeed, Min Tārīkh al-Nahwu, (Kuwait: Maktabat al-Falāh,1980), p. 27. See also, Al- Najaār Muhammad Abdul Aziz, Diyā'a al-Sālikīn ilā Awḍh al-Masālik, vol. 1, (Cairo: Mahtabat Ibn Taymiyyah, undated), p. 13.

49. Izzual al- Din Ismail, Al-Masādir al-Adabiyyah wa al-Lugawiyyah, fi al-Turāth al-Arabì. (Beirut: Dar al-Nahdah al-Arabiyyah, 1975), pp. 132-277.

\section{BIBLIOGRAPHY}

1. Al-Afghani, Saeed, Min Tārīkh al-Nahwu, Kuwait: Maktabat al-Falaah, 1980.

2. Al-Hassan, Mohammad al-Bashir \& Mohammad Tayib Abdallah, Al-Adab wa al-Nusūs, Al- 'Asr al-Jāhilī, 9 ${ }^{\text {th }}$ ed. Dar al-Nashir al-Tarbāwī, 1994.

3. Al-Fārābī, Kitāb Al-khurūf (Book of Letters), edited by Muhsin Mahdi, $2^{\text {nd }}$ ed. Beirut: Dar el-Mashreq Publishers, 1990.

4. Farrukh, Umar, Al- Fikr Al- 'Arabī. Beirut: Dar 'ilm Lilmalāyīn, 1996.

5. Musah, Mohammad Othoman Mohammad, Al-Adab wa al-Nūsus, al-'Asr alAmawī Abassi, ${ }^{\text {th }}$ ed. Dar Al-Majid Litibaa. 1994.

6. M.M. Sharif, A History of Muslim Philosophy, Vol. 2, Wiesbaden, 1968.

7. Al-Asad Nasir al-addin, Masadir al-Shiar al- Jāhilī wa Quiyamuha alTarikhiyyah, $7^{\text {th }}$ ed. Beirut: Dar al- Jil, 1988.

8. Daif, Shawqi, Tarikh al-Adab al-Arab, $6^{\text {th }}$ ed. Cairo: Dar al- Maarif, 1966.

9. Daif, Shawqi, Tarikh al-Adab al-Arab, $2^{\text {nd }}$ ed. Cairo: Dar al- Maarif, 1973.

10. Daif Shawqi, Al-Fannu wa Mazahibuhu fi al-shiar al- 'Arabi, $9^{\text {th }}$ ed. Cairo: Dar Maarif, 1960.

11. Al-Majali, Jihad, Tabaqat al-Shuara fi al-Naqdi al-Adabi inda al-Arab. $1^{\text {st }}$ ed. Beirut: Dar al-Jil, 1992.

12. Al-Rufai, Anwar, Al-Islam fi Hadāratihi wa Nuzumihi, $3^{\text {rd }}$ ed. Dimashq: Dar alFikr, 2002.

13. Al-Janabi, Abdul Karim Ibrahim, Tārikh al-Khitābah al-'Arabiyyah. Cairo: Maktabat al-Thaqāfiyyah al-Dīniyyah, 2005.

14. Abbass, Ihsan, Tarikh al-Naqd al-Adabi inda al-'Arab. Amman: Dar al-Shuruq, 1993.

15. Al-Najjar, Mohammad Abdul-Aziz, Diyāu al-Salik ila Awdah al-Masalik, Cairo: Maktabat Ibn Taymiyyah, undated. Vol.1

16. Saba, Tawfiq Mohammad, Qiyam Hadariyyah fi al-Quran al-Karim. Cairo: Dar al-Manar, 1984.

17. Abdul-Baqi, Mohammad Fuad, Al-Lua lua wa al-Marjan. Cairo: Dar al-hadith, 2007.

18. Muhammad bin Ismail, Sahih al-Bukhari, $6^{\text {th }}$ ed., edited by Nassar, Mahmud Mohammad. Beirut: Dar Al- Kutub Al-'Ilmiyyah, 2009.

19. Ibn al-Muqqafa, Abdul-Allah Kalilah wa Dimnah, $1^{\text {st }}$ ed. Dimashq: Dar Kiram, undated. 
20. Dermenghem, Emile, Les plus Beaux Textes Arabes. Paris: Editiona du vieux colombier, 1951.

21. The Journal of the Royal Asiatic Society, 1905.

22. Al-Jāhiz, Al-Hayawān, edited by Abdu al-Salam Harun, $3^{\text {rd }}$ ed. Beirut: Dar alKitab, 1969.

23. Al-Jāhiz, Abu 'Usman 'Amru bin Bahr, Al-Bayān wa al-Tabyīn, edited by Abdu al-Salam Harun, $2^{\text {nd }}$ ed. Cairo: Maktatabat al-khanji in Egypt and Al-Muthana in Baghdad, 1960.

24. H. Kilpatrick, 'Adab', Encyclopaedia of Arabic Literature. London, 1998.

25. Izzual al-Din Ismail, Al-Masadir al-Adabiyyah wa al-Lugawiyyah, fi al-Turath al-Arabi. Beirut: Dar al-Nahdah al-Arabiyyah, 1975. 